\title{
Assessment of fluid responsiveness during prone position in ards. a validation study
}

\author{
J-C Richard ${ }^{1,2,3^{*}}$, H Yonis ${ }^{1,2}$, F Bayle ${ }^{1}$, F Gobert ${ }^{1,2}$, R Taponnier ${ }^{1}$, V Leray ${ }^{1}$, C Guérin ${ }^{1,2,4}$ \\ From ESICM LIVES 2015 \\ Berlin, Germany. 3-7 October 2015
}

\section{Introduction}

Predicting fluid responsiveness is of paramount importance to avoid unnecessary fluid administration in ARDS patients, since a positive fluid balance is associated with ARDS mortality [1]. Several tests with high reliability to predict fluid responsiveness are now available, but none have been validated in the prone position (PP) in ARDS patients, while this treatment is now a cornerstone of the therapeutic armamentarium of severe ARDS [2].

\section{Objectives}

To evaluate the diagnostic performance of three methods to predict fluid responsiveness in PP: cardiac index variation during the Trendelenburg position and an end-expiratory occlusion, and pulse pressure variation after increasing tidal volume (VT) to $8 \mathrm{ml} . \mathrm{kg}^{-1}$ predicted body weight (PBW).

\section{Methods}

This study is a prospective single-center study, performed on ARDS patients in PP, monitored with the PiCCO device, and with acute circulatory failure. Patients were studied at baseline with bed angulation $13^{\circ}$, during a 1-min postural change in the Trendelenburg position with bed angulation $-13^{\circ}$, during a $1 \mathrm{~min}$ increase of VT to $8 \mathrm{ml} . \mathrm{kg}^{-1} \mathrm{PBW}$, during a 15 -s end-expiratory occlusion and after IV infusion of $500 \mathrm{ml}$ crystalloids. Patients were returned to baseline settings after each intervention. Fluid responsiveness was deemed present if cardiac index assessed by thermodilution increased by at least $15 \%$ after fluid administration.

\section{Results}

19 patients (SAPS II 56 (48-62)) were included at the time of abstract submission. VT was $6.0(5.9-6.2) \mathrm{ml}^{\mathrm{kg}}{ }^{-1} \mathrm{PBW}$,

${ }^{1}$ Hospices Civils de Lyon, Service de Réanimation Médicale - Hôpital de la Croix-Rousse, Lyon, France

Full list of author information is available at the end of the article
$\mathrm{PaO}_{2} / \mathrm{FiO}_{2}$ ratio $158 \mathrm{~mm} \mathrm{Hg}$ (116-201), PEEP 8 (6-10) $\mathrm{cm}$ $\mathrm{H}_{2} \mathrm{O}$, and plateau pressure $23(20-27) \mathrm{cm} \mathrm{H}_{2} \mathrm{O} .7$ patients (37\%) were deemed fluid-responsive after fluid administration. The area under ROC curve of the pulse contour derived cardiac index during the Trendelenburg maneuver and the end-expiratory occlusion test were 0.91 (95\% CI: $0.77-1$ ) and 0.45 (95\% CI: 0.17-0.73), respectively. An increase in cardiac index $\geq 8 \%$ during the Trendelenburg maneuver enable to diagnose fluid responsiveness with a sensitivity of $71 \%$ (95\% CI: $43-100 \%$ ), and a specificity of 100\% (95\% CI: 100-100\%). Cardiac arrhythmia were present at baseline in 11 patients (58\%), which were therefore excluded from pulse pressure variation analysis. The area under ROC curve of pulse pressure variation during VT increase to $8 \mathrm{ml} . \mathrm{kg}^{-1} \mathrm{PBW}$ was 0.50 (95\% CI: 0.04-0.96).

\section{Conclusions}

Cardiac output measurement during a Trendelenburg maneuver is a reliable method to assess fluid responsiveness in ARDS patients in the prone position.

\section{Trial Registration}

Clinical trial registered with www.clinicaltrials.gov (NCT01965574).

\section{Authors' details}

${ }^{1}$ Hospices Civils de Lyon, Service de Réanimation Médicale - Hôpital de la Croix-Rousse, Lyon, France. ' Université de Lyon - Université Lyon I, Lyon, France. ${ }^{3}$ CREATIS INSERM 1044 CNRS 5220, Villeurbanne, France. ${ }^{4}$ IMRB INSERM 955, Equipe 13, Creteil, France.

Published: 1 October 2015

\section{References}

1. Sakr Y, Vincent JL, Reinhart K, Groeneveld J, Michalopoulos A, Sprung CL, et al: High tidal volume and positive fluid balance are associated with worse outcome in acute lung injury. Chest 2005, 128(5):3098-3108.

2. Guerin C, Reignier J, Richard J-C, Beuret P, Gacouin A, Boulain T, et al: Prone positioning in severe acute respiratory distress syndrome. $N$ Engl J Med 2013, 368(23):2159-2168. 
doi:10.1186/2197-425X-3-S1-A591

Cite this article as: Richard et al: Assessment of fluid responsiveness

during prone position in ards. a validation study. Intensive Care Medicine

Experimental 2015 3(Suppl 1):A591.

\section{Submit your manuscript to a SpringerOpen ${ }^{\circ}$ journal and benefit from:}

- Convenient online submission

- Rigorous peer review

- Immediate publication on acceptance

- Open access: articles freely available online

- High visibility within the field

- Retaining the copyright to your article

Submit your next manuscript at $\gg$ springeropen.com 